\title{
EVALUASI KEMAMPUAN DAN PENGHITUNGAN PERINGKAT SISWA MENGGUNAKAN METODE TOPSIS DAN ENTROPY
}

\author{
MUHAMMAD GALIH, SITI ROHANA \\ Politeknik Negeri Tanah Laut, MTsN 1 Tanah Laut \\ Email: ghalih@politala.ac.id
}

\begin{abstract}
:
In this study uses techniques for order preference by similarity to ideal solution (TOPSIS) combined within formation Entropy weight to examine the performance of 5 best students. Calculations in teaching and research and improvement ability reveal the short-term and long-term performance. Exact values and intervals characterize the attribute values in the current model. A comparison and experimental analysis show the applicability, feasibility, effectiveness, and advantages of the proposed method. In this study focus on the TOPSIS and Entropy to calculate the student's performance. First, in this study the rationality of TOPSIS conferring to the standard decision theory. It forms that TOPSIS also has a built-in multi-attribute value meaning that not revealed explicitly. To this point, this has been a unknown feature of TOPSIS. Second, Entropy applied for the decision maker's (DM) behavioral propensity into TOPSIS. Finally, to advance evaluation accuracy of student performance, TOPSIS and Entropy applied to ranking the student with several criteria such as Presence (C1), Assignment (C2), Attitude (C3), Midterm-Exam (C4), and Final Exam (C5).
\end{abstract}

Keywords: Evaluation, Entropy, Performace, Student, TOPSIS

\section{PENDAHULUAN}

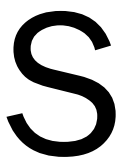
alah satu tugas utama guru adalah mengawasi siswa tentang kemajuan pengembangan pengetahuan dan akademik. Laporan atau pengawasan pengembangan pendidikan disusun setiap tahun, berdasarkan hasil kinerja dan kemampuan siswa yang akan menjadi dasar atau tolak ukur untuk menentukan peringkat siswa. Selanjutnya, akademik adalah dasar untuk pelaksanaan prinsip pembangunan berkelanjutan. Seorang pendidik atau Guru adalah salah satu sumber yang penting dan sangat berpengaruh pada peningkatan kualitas pendidikan, terutama dalam mewujudkan pendidikan berkualitas. Banyak spesialis dalam ilmu pendidikan memfokuskan perhatian mereka pada efektivitas gaya mengajar ataupun metode dalam pendidikan. Ditambah lagi, Guru adalah salah satu unsur yang sangat penting dalam mewujudkan akuntabilitas penyediaan dan penyampaian layanan pendidikan yang berkualitas.

Oleh karena itu, tanpa guru yang berkualitas, upaya untuk meningkatkan kualitas pendidikan akan semakin sulit terlaksana. Selain itu, Guru juga memiliki peran yang harus selalu dipertimbangkan dalam membimbing, mengarahkan, dan mendidik siswa dalam proses pembelajaran baik di sekolah maupun di luar lingkungan sekolah. Guru memiliki peran yang lebih menonjol dalam menciptakan 
proses pengajaran dan pembelajaran yang berkualitas. Keunggulan dan proses belajar mengajar harus dipelajari dari pengaruh kualifikasi dan kinerja guru, di mana kinerja guru yang berkualitas akan meningkatkan keunggulan pendidikan di sekolah. Sebuah korelasi konstruktif antara sikap dan motivasi juga ditentukan, dan itu menentukan bahwa korelasi lebih tinggi pada siswa formasi akademik. Peningkatan kualitas pendidikan bukanlah tugas yang rumit tidak hanya berkaitan dengan permasalahan teknis, tetapi mencakup berbagai persoalan yang sangat rumit dan kompleks, baik yang menyangkut perencanaan, pendanaan maupun efesiensi dan efektivitas penyelenggaraan sistem sekolah(Syamsuddin, 2017). Ketika Guru melakukan sebuah evaluasi, maka hal ini dapat mendorong siswa untuk lebih giat belajar secara terus menerus dan juga mendorong guru untuk lebih meningkatkan kualitas proses pembelajaran serta mendorong sekolah untuk lebih meningkatkan fasilitas dan kualitas belajar siswa(Manirah, 2017). Selain itu, di antara berbagai pendekatan untuk manajemen konflik, Multi-Kriteria Pengambilan Keputusan (MCDM) sangat umum digunakan. Multi criteria decision making (MCDM) adalah suatu metode pengambilan keputusan untuk menetapkan alternatif terbaik dari sejumlah alternatif berdasarkan beberapa kriteria tertentu. MCDM memiliki dua kategori yakni Multiple Objective Decision Making (MODM) dan Multiple Attribute Decision Making (MADM), di mana proses MCDM dapat menjadi proses yang kompleks dan dinamis juga pada tingkat pengambilan keputusan. Dapat dirujuk pada batasan di atas, dalam studi ini metodologi Technique For Order Preference By Similarity To Ideal Solution (TOPSIS) akan digunakan untuk menyelesaikan kinerja siswa untuk mengidentifikasi opsi terbaik, Technique For Order Preference By Similarity To Ideal Solution (TOPSIS) adalah suatu alternatif yang dipilih memiliki jarak terdekat dengan solusi ideal positif dan memiliki jarak terjauh dari solusi ideal negatif. Metode TOPSIS digunakan agar mendapatkan perankingan untuk alternatif yang ada berdasarkan nilai preferensi terbesar hingga terkecil. Namun, metode ini memerlukan bobot priotitas untuk mengelolah data selanjutnya, bobot tersebut didapat menggunakan metode pembobotan entropy. Metode Pembobotan Entropy dapat diaplikasikan untuk memberikan bobot pada setiap kriteria. Bobot kriteria dalam suatu penilaian ditentukan melalui opini pengambil keputusan Terlebih lagi, pendekatan Entropy akan dimasukkan dalam prosedur TOPSIS dengan tujuan untuk menyediakan alternatif untuk proses pemeringkatan skoring nilai.

Pada studi lain banyak peneliti yang menggunakan teknik TOPSIS dikombinasikan dengan informasi entropy, seperti yang dilakukan oleh Rupang dan Kusnadi mereka menggunkan metode ini untuk Sistem Pendukung Keputusan Pemilihan Karyawan Terbaik(Rupang \& Kusnadi, 2018). Senada dengan penelitian sebelumnya oleh Sucipto, dkk yang berfokus pada Sistem Pendukung Keputusan Penerimaan Siswa Baru dan Penjurusan Pada Sekolah Menengah Kejuruan(SMK)(Sucipto, Kusrini, \& Fatta, 2017). Selain itu, Faesal, dkk juga 
menerapkan Metode AHP dan TOPSIS untuk menentukan Mutu Dosen (Faesal, Fauziati, \& Soesanti, 2017). Ditambah penelitian terbaru oleh Chandra tentang Penilaian Kinerja Dosen Menggunakan Metode TOPSIS (Studi Kasus : AMIK Mitra Gama)(Candra Surya, 2018).

Di antara keuntungan dari TOPSIS secara logis merupakan dasar pemikiran pilihan manusia dengan mempertimbangkan kedua kreteria terbaik dan terburuk dari alternatif secara bersamaan, diwakili oleh nilai skalar, kesederhanaan perhitungan dan presentasi. Jumlah kreteria tidak mempengaruhi jumlah langkah penghitungan. Dengan demikian metode ini menawarkan solusi yang lebih cepat. Namun demikian, dalam penelitian ini akan berfokus pada manajemen pendidikan untuk mengevaluasi kinerja dan kemampuan siswa menggunakan pendekatan TOPSIS dan Entropy.

\section{KAIIAN TEORI}

Metode pengambilan keputusan multi kriteria (MCDM) telah menjadi produsen di beberapa bidang penelitian. Seperti penelitian yang telah dilakukan oleh Dyah Herawatie dan Eto Wuryanto yang berjudul Sistem Pendukung Keputusan Pemilihan Mahasiswa Berprestasi dengan Metode Fuzzy TOPSIS (Herawatie \& Wuryanto, 2017). Mutu pendidikan sering diartikan sebagai karakteristik jasa pendidikan yang sesuai dengan kriteria tertentu untuk memenuhi kepuasan pengguna (user) pendidikan, yakni peserta didik, orang tua, serta pihak-pihak berkepentingan lainnya. Dalam menjaga mutu proses tersebut, diperlukan adanya quality control yang mengawasi jalannya proses dan segala komponen pendukungnya(Ahmad, 2017).

Pengambilan keputusan adalah studi tentang mengidentifikasi dan memilih alternatif berdasarkan nilai dan preferensi pembuat keputusan. Matriks pengambilan keputusan diterapkan sebagai salah satu alat yang kuat untuk proses keputusan yang dirancang berdasarkan susunan dasar persegi panjang yang ditentukan dalam baris dan kolom. Metode yang diterapkan pada sistem adalah metode Techinique for Order Preference by Similarity to Ideal Solution (TOPSIS) sebagai metode perankingan dan metode Entropy sebagai metode pembobotan kriteria(Maisari, Andreswari, \& Efendi, 2017). Metode TOPSIS yang mulanya diusulkan oleh Hwang dan Yoon pada tahun 1981 dan digunakan di banyak bidang aplikasi (Marbun \& Sinaga, 2017). Metodologi ini awalnya dirancang untuk memecahkan masalah peringkat. Bahkan, TOPSIS menyediakan peringkat alternatif berdasarkan skor kesamaan, di mana skor kemiripan masing-masing alternatif adalah fungsi jarak antara alternatif dan beberapa tolok ukur yang biasa disebut sebagai solusi ideal positif dan negatif.

Selain itu, Entropy Weight Method (EWM) didasarkan pada entropi Shannon, awalnya dikembangkan oleh Shannon dan Weaver, pada tahun 1947. Shannon entropy adalah konsepsi yang direkomendasikan sebagai ukuran ketidakpastian 
dalam informasi, dinyatakan dalam teori kemungkinan. Dalam tulisan ini, proses TOPSIS mulai membuat matriks data asli dengan menggunakan nilai kriteria untuk setiap alternatif.

Langkah 1. Membuat matriks evaluasi data siswa

$$
\begin{aligned}
& \begin{array}{llll}
C_{1} & C_{2} & \cdots & C_{n}
\end{array} \\
& D=\left[x_{i j}\right]_{m \times n}=\begin{array}{c}
A_{1} \\
A_{2} \\
\vdots \\
A_{m}
\end{array}\left[\begin{array}{cccc}
x_{11} & x_{12} & \cdots & x_{1 n} \\
x_{21} & x_{22} & \cdots & x_{2 n} \\
\cdots & \cdots & \cdots & \cdots \\
x_{m 1} & x_{m 2} & \cdots & x_{m n}
\end{array}\right]_{m \times n} \\
& i=1,2, \ldots, m, j=1,2, \ldots, n
\end{aligned}
$$

Langkah 2. Normalisasi matriks

$$
\begin{aligned}
& r_{i j}=\frac{x_{i j}}{\sqrt{\sum_{i=1}^{m} x_{i j}^{2}}} \\
& i=1,2, \ldots, m, j=1,2, \ldots, n \\
& \begin{array}{llll}
C_{1} & C_{2} & \cdots & C_{n}
\end{array} \\
& R=\left[r_{i j}\right]_{m \times n}=\begin{array}{c}
A_{1} \\
A_{2} \\
\vdots \\
A_{m}
\end{array}\left[\begin{array}{cccc}
r_{11} & r_{12} & \cdots & r_{1 n} \\
r_{21} & r_{22} & \cdots & r_{2 n} \\
\cdots & \cdots & \cdots & \cdots \\
r_{m 1} & r_{m 2} & \cdots & r_{m n}
\end{array}\right]_{m \times n} \\
& i=1,2, \ldots, m, j=1,2, \ldots, n
\end{aligned}
$$

Langkah 3. Hitung berat obyektif dengan Entropy

$$
\begin{aligned}
e_{j}=- & \frac{1}{\ln m} \sum_{i=1}^{m} r_{i j} \ln r_{i j} \\
& i=1,2, \ldots, m, j=1,2, \ldots, n
\end{aligned}
$$

Hitung ulang nilai setiap kriteria evaluasi

$$
\begin{aligned}
& W=\left(w_{1}, w_{2}, \ldots, w_{n}\right) \\
& w_{j}=\frac{1-e_{j}}{\sum_{j=1}^{n}\left(1-e_{j}\right)} \\
& i=1,2, \ldots, m, j=1,2, \ldots, n
\end{aligned}
$$


Langkah 4. Matriks bobot

$$
\begin{gathered}
v_{i j}=r_{i j} \times w_{j} \\
V=\left[v_{i j}\right]_{m \times n} \\
\quad i=1,2, \ldots, m, j=1,2, \ldots, n
\end{gathered}
$$

Langkah 5. Hitung solusi ideal positif dan negatif

$$
\begin{aligned}
& V^{+}=\left\{v_{1}^{+}, v_{2}^{+}, \ldots, v_{n}^{+}\right\} \\
& V^{-}=\left\{v_{1}^{-}, v_{2}^{-}, \ldots, v_{n}^{-}\right\}
\end{aligned}
$$

Langkah 6. Hitung jarak antara sampel yang dievaluasi dan solusi ideal positif dan negatif

$$
\begin{gathered}
S_{i}^{+}=\sqrt{\sum_{j=1}^{n}\left(v_{i j}-v_{j}^{+}\right)^{2}} \\
i=1,2, \ldots, m, j=1,2, \ldots, n \\
S_{i}^{-}=\sqrt{\sum_{j=1}^{n}\left(v_{i j}-v_{j}^{-}\right)^{2}} \\
i=1,2, \ldots, m, j=1,2, \ldots, n
\end{gathered}
$$

Langkah 7. Hitung nilai indikator kemampuan relatif siswa

$$
C_{i}=\frac{S_{i}^{-}}{S_{i}^{+}+S_{i}^{-}}
$$

Langkah 8. Menyortir (Peringkat)

Menurut nilai jarak relatif dari masing-masing sampel evaluasi $\mathrm{Ci}$, itu adalah pro dan kontra relatif dari setiap sampel evaluasi setelah evaluasi. $0<\mathrm{Ci}<1, \mathrm{Ci}$ semakin dekat nilainya menjadi 1 , semakin dekat sampel evaluasi ke solusi ideal positif; itu juga berarti bahwa di bawah kriteria evaluasi yang ada, ilustrasi evaluasi adalah sampel evaluasi terbaik yang relatif terhadap sampel evaluasi lainnya. Sebaliknya, jika nilai Ci lebih jauh terpisah satu sama lain, itu berarti bahwa sampel evaluasi merupakan sampel evaluasi yang buruk dan ada ruang yang cukup untuk perbaikan.

\section{METODE PENELITIAN}

Metode penelitian yang digunakan adalah observasi, observasi ini dilaksanakan di MTsN 1 Tanah Laut dengan subjek siswa yang ada di lingkup MTsN 1 Tanah Laut. 


\section{HASIL PENELITIAN DAN PEMBAHASAN}

Sebelum memulai studi, izin etis yang diperoleh dari program matematika yang dikembangkan untuk alasan ini memungkinkan seseorang untuk memperoleh koefisien entropi terboboti dan output dari metode TOPSIS. Ini menunjukkan bahwa indeks bahan yang dianggap di atas pada Tabel 1 diasumsikan sebagai ukuran independen dari masing-masing parameter kinerja yang sesuai. Kehadiran (C1), Tugas (C2), Sikap (C3), Ujian Tengah Semester (C4), dan Ujian Akhir (C5). Dengan demikian, penelitian ini telah mendorong pertanyaan penting untuk penelitian di masa depan tentang kinerja siswa dan metode guru untuk menghitung kinerja siswa.

Tujuannya adalah untuk mengoptimalkan setiap indeks, terlepas dari nilainilai properti material individual yang didefinisikan dalam indeks itu. Selanjutnya, nilai optimum awal dari setiap kriteria adalah independen dari nilai kriteria lain (yaitu, tidak ada interaksi yang dapat diterima). Namun, ketika kriteria ini digunakan dengan metode TOPSIS yang tidak dapat memperlakukan properti material sebagai kriteria individu, hasil peringkat yang diperoleh dalam pekerjaan ini mungkin tidak rentan terhadap inklusi dari indeks. Analisis berfokus pada lima ukuran kriteria untuk menghitung kinerja dan kemampuan siswa. Temuan yang paling menarik adalah bahwa nilai aktual yang dihitung dengan persamaan langkah 3 oleh Entropy ditunjukkan pada Tabel 2.

Tabel 1. Matriks kinerja siswa yang dinormalisasi

\begin{tabular}{llllll}
\hline & C1 & C2 & C3 & C4 & C5 \\
\hline A1 & 80 & 79 & 90 & 85 & 90 \\
A2 & 75 & 85 & 93 & 89 & 97 \\
A3 & 90 & 88 & 90 & 90 & 95 \\
A4 & 78 & 89 & 95 & 78 & 88 \\
A5 & 86 & 90 & 94 & 87 & 89 \\
\hline
\end{tabular}

Tabel 2. Nilai obyektif dengan Entropy

\begin{tabular}{llllll}
\hline & C1 & C2 & C3 & C4 & C5 \\
\hline A1 & -0.3619 & -0.3656 & -0.3620 & -0.3608 & -0.3616 \\
A2 & -0.3656 & -0.3611 & -0.3593 & -0.3564 & -0.3543 \\
A3 & -0.3493 & -0.3581 & -0.3620 & -0.3552 & -0.3566 \\
A4 & -0.3636 & -0.3569 & -0.3573 & -0.3660 & -0.3632 \\
A5 & -0.3551 & -0.3557 & -0.3583 & -0.3587 & -0.3624 \\
\hline
\end{tabular}

Tabel 3 merangkum koefisien tertimbang indeks kinerja yang berbeda yang diperoleh dengan menggunakan metode entropi, dengan atau tanpa mempertimbangkan kriteria. Selain itu, Tabel 4 menunjukkan peningkatan urutan menurut peringkat umum, yang menggambarkan siswa. Analisis lebih lanjut menunjukkan bahwa peringkat akhir siswa tampaknya A3, A5, dan A3 adalah tiga siswa terbaik di kelas. 
Tabel 3. Solusi ideal positif dan negatif

\begin{tabular}{llllll}
\hline & C1 & C2 & C3 & C4 & C5 \\
\hline$V_{j}^{+}$ & 0.0972 & 0.0933 & 0.0927 & 0.0936 & 0.0948 \\
$V_{j}^{-}$ & 0.0810 & 0.0819 & 0.0878 & 0.0811 & 0.0860 \\
\hline
\end{tabular}

Tabel 4. Peringkat siswa

\begin{tabular}{llc}
\hline & Hasil & Peringkat \\
\hline A1 & 0.333161 & 5 \\
A2 & 0.482413 & 3 \\
A3 & 0.806108 & 1 \\
A4 & 0.372641 & 4 \\
A5 & 0.670622 & 2 \\
\hline
\end{tabular}

\section{SIMPULAN}

Kesimpulan Dalam artikel ini, penerapan pendekatan berbagai kriteria keputusan untuk evaluasi kinerja siswa dibahas. Hasil yang diperoleh dari dua metode analisis TOPSIS dan Entropy adalah teknik yang dapat diandalkan untuk memprioritaskan alternatif mengenai kedekatannya dengan solusi ideal sedemikian rupa sehingga alternatif yang dipilih harus memiliki jarak terpendek dari solusi ideal dan jarak terpanjang dari solusi disfungsional. Sementara itu, basis metode-metode ini berbeda, perbedaan hasil akhir dari evaluasi dibenarkan. Kinerja guru dan siswa memiliki peran yang lebih penting dalam Pendidikan. Peringkat kinerja siswa merupakan perhatian strategis dan memiliki dampak signifikan pada efisiensi manajemen pendidikan, ini terlihat dari hasil kinerja siswa dimana A3 dan A5 memperoleh peringkat 1 dan 2. Beberapa alternatif harus dipertimbangkan dan dievaluasi mengenai banyak kriteria konflik yang berbeda dalam masalah manajemen pendidikan, yang mengarah ke serangkaian luas data subjektif atau ambigu dari hasilnya. Oleh karena itu, pendekatan evaluasi yang memadai sangat penting untuk meningkatkan kualitas keputusan. Studi ini, menyajikan kerangka kerja ilmiah untuk menilai manajemen pendidikan di sekolah untuk mendapatkan informasi lebih lanjut tentang kinerja siswa. Meskipun model dikembangkan dan diuji untuk digunakan dalam kinerja siswa, itu juga dapat digunakan dengan sedikit modifikasi dalam masalah pengambilan keputusan lainnya dalam manajemen pendidikan. Juga, model matematika yang dikombinasikan dengan model yang diusulkan. Ini akan meningkatkan metode yang diusulkan dan merupakan salah satu arah dalam penelitian masa depan. 


\section{DAFTAR PUSTAKA}

Ahmad, L. O. I. (2017). Konsep Penilaian Kinerja Guru Dan Faktor yang Mempengaruhinya. Jurnal Idaarah, I(1), 133-142.

Candra Surya. (2018). Penilaian Kinerja Dosen Menggunakan Metode TOPSIS (Studi Kasus: AMIK Mitra Gama). Jurnal RESTI (Rekayasa Sistem Dan Teknologi Informasi), 2(1), 322-329.

Faesal, A., Fauziati, S., \& Soesanti, I. (2017). Implementasi Metode AHP dan TOPSIS untuk menentukan Mutu Dosen. Seminar Nasional TIK Dan IImu Sosial (SocioTech) 2017, 7-13.

Herawatie, D., \& Wuryanto, E. (2017). Sistem Pendukung Keputusan Pemilihan Mahasiswa Berprestasi dengan Metode Fuzzy TOPSIS. Journal of Information Systems Engineering and Business Intelligence, 3(2). https://doi.org/http://dx.doi.org/10.20473/jisebi.3.2.92-100

Maisari, K. D., Andreswari, D., \& Efendi, R. (2017). Pembobotan Entropy Untuk Penentuan Calon Penerima Bantuan Siswa Miskin ( BSM ) APBD Kota Bengkulu ( Studi Kasus: SMAN 8 Kota Bengkulu ). Jurnal Rekursif, 5(2). Retrieved from http://ejournal.unib.ac.id/index.php/rekursif/

Manirah. (2017). Evaluasi belajar peserta didik (siswa). Jurnal Idaarah, I(36), 257267.

Marbun, M., \& Sinaga, B. (2017). Sistem Pendukung Keputusan Penilaian Hasil Belajar Mahasiswa Dengan Metode TOPSIS di Stmik Pelita Nusantara Medan. Jurnal Manajemen Dan Informatika Pelita Nusantara, 1(2), 9-15.

Rupang, M. A., \& Kusnadi, A. (2018). Implementasi Metode Entropy dan Topsis Dalam Sistem Pendukung Keputusan Pemilihan Karyawan Terbaik. ULTIMA Computing, $X(1), 13-18$.

Sucipto, H., Kusrini, \& Fatta, H. Al. (2017). Sistem Pendukung Keputusan Penerimaan Siswa Baru dan Penjurusan Pada Sekolah Menengah Kejuruan(SMK). Jurnal Ekonomi Dan Teknik Informatika, 5(2).

Syamsuddin. (2017). Penerapan Fungsi-Fungsi Manajemen Dalam Meningkatkan Mutu Pendidikan. Jurnal Idaarah, I(1), 3-4. 